\title{
Biomarkers in Diagnosis and Prediction of Hepatocellular Carcinoma Recurrence (Review)
}

\author{
DOI: $10.17691 / \mathrm{stm} 2019.11 .2 .23$
}

Received March 21, 2019

\begin{abstract}
S.I. Malov, MD, PhD, Assistant, Department of Infectious Diseases ${ }^{1}$; Senior Researcher, Central Scientific Research Laboratory2;

I.V. Malov, MD, DSc, Professor, Head of the Department of Infectious Diseases ${ }^{1}$;

V.V. Dvornichenko, MD, DSc, Professor, Head of the Department of Oncology and Radiotherapy'; Head of the Oncology Department';

P.N. Marche, PhD, Professor, Vice Director of Research Center ${ }^{3}$;

T. Decaens, PhD, Professor, Research Director, Laboratory Head of Department

of Hepatology and Gastroenterology4;

Z. Macek-Jilkova, PhD, Researcher of Department of Hepatology and Gastroenterology4;

N.D. Yushchuk, MD, DSc, Professor, Academician of the Russian Academy of Sciences, Head of the Department of Infectious Diseases and Epidemiology 5

${ }^{1}$ Irkutsk State Medical University, 1 Krasnogo Vosstaniya St., Irkutsk, 664003, Russia;

2Irkutsk State Medical Academy of Postgraduate Education, a Branch of the Russian Medical Academy of Continuing Professional Education, 100 Yubileyny Microdistrict, Irkutsk, 664049, Russia;

${ }^{3}$ Institute for Advanced Biosciences, Research Center Inserm U1209, CNRS 5309, Univ. Grenoble-Alpes,

La Tronche, 38700, France;

${ }^{4} \mathrm{CHU}-G r e n o b l e$, Clinique Universitaire d'Hépato-Gastroentérologie, La Tronche, 38700, France;

${ }^{5}$ A.I. Yevdokimov Moscow State University of Medicine and Dentistry, 20 Delegatskaya St., Moscow,

127473, Russia
\end{abstract}

\begin{abstract}
Hepatocellular carcinoma (HCC) is the second leading cause of death in oncological patients. The prognosis of the disease outcome depends directly on its timely detection. Currently, in the majority of countries, the diagnostic algorithm at the preclinical stage of tumor development includes determination of alpha-fetoprotein in combination with instrumental imaging techniques. This approach allows the detection of about $65-80 \%$ of liver tumors at an early stage (A according to the BCLC classification), whereas at a very early stage (0 according to the BCLC classification) only $32-50 \%$ of cases, the result which cannot be considered satisfactory. In this regard, the search for effective biomarkers of hepatocellular carcinoma is an important challenge that faces the world healthcare.

Advances in proteomics and genomics have led to the discovery of numerous promising markers which are now being clinically tested. Molecules of protein nature proposed as hepatocellular carcinoma tumor markers in different periods of time are described in this review. Comparative data on their effectiveness and specificity are also presented. The possibility of isolated or combined use of these biomarkers for risk assessment and early diagnosis of primary liver cancer is considered.
\end{abstract}

Key words: hepatocellular carcinoma; screening; biomarkers; proteomics.

\section{Introduction}

Annually, about 700,000 diseases of hepatocellular carcinoma (HCC) are registered worldwide [1, 2]. Prevalence of liver cancer stands fifth among oncological diseases [3, 4] and in recent years, HCC moved from the third to the second place among the causes of death of oncological patients [5-8]. HCC-related morbidity rate (per 100,000 population) varies in different countries from 1.7 in Northern Europe and Canada to 30.0 in China where more than half of all cases of liver cancer is registered [9-11]. In Russia, 6-8 thousand new HCC cases are registered every year (4.0-5.0 cases per 100,000 population) which corresponds to an average rate of morbidity [12]. Worldwide, HCC occurs 3 times more often in men than in women $[9,13,14]$. Besides, there are substantial differences in HCC incidence in the representatives of various races: Mongoloids suffer from the disease 2 times more often than Negroids, while the Hispanics 2 times more often than white Americans [13].

Hepatocellular carcinoma develops more commonly in patients with liver cirrhosis (LC) caused by hepatitis viruses $\mathrm{B}$ and $\mathrm{C}$, chronic alcohol abuse, and nonalcoholic fatty liver disease $[12,15,16]$.

Since there are no clinical symptoms at an early stage of the disease, $\mathrm{HCC}$ is diagnosed late in $60 \%$ of patients and often concurrently with multiorgan metastasizing [1, 3]. If a tumor is detected at an early stage, the prognosis

Corresponding author: Sergey I. Malov, e-mail: LYNX2000@mail.ru 
is relatively good and 5-year survival exceeds 70\% [5, 17-21].

All the above-said dictates the necessity of conducting active investigations and finding serum HCC biomarkers which are cost-effective and available for a wide screening [15, 22, 23].

Special attention is paid to the search for HCC biomarkers which would allow the tumors to be diagnosed with a high degree of probability at early stages when instrumental methods are yet ineffective $[24,25]$. It is useless to apply oncomarkers at the advanced stage as ultrasound examination, computed tomography, and magnetic resonance imaging show high diagnostic sensitivity (Se) [26, 27].

Practical application of biomarkers is connected with the degree of their clinical trial. Five phases of biomarker validation are distinguished and their stepwise implementation provides the possibility to make an objective conclusion about their effectiveness (Table 1) $[5,28,29]$.

At present, a great variety of biomarkers are declared at the preclinical stage. But though their possible usage is theoretically grounded and some limited clinical observations have been obtained, wide multicenter studies proving their actual value are absent [3].

The search for HCC biomarkers is being carried out in three principal directions: examination of protein markers (proteomics), nucleic acids and their polymorphisms (genomics), and determination of metabolites in blood and urine (metabolomics) [5, 19, 29-34]. In this work, information about protein oncomarkers, which are now of special interest, is overviewed. This is caused by the fact that methods of various protein indication are rather well automated, have high Se and reproducibility. Application of genomic oncomarkers in clinical practice is less common, the results of their identification vary greatly depending on the way of nucleic acid isolation, biological substrate, indication method. Serum and urine metabolites in cancerogenesis require further investigation, e.g. determination of a cut-off level for some specific metabolite typical for oncological disease. In other words, questions of specificity (Sp) in metabolomics acquire special importance when a diagnostic value of an oncomarker is concerned. Currently, canavanine succinate, glycochenodeoxycholic acid, and other organic acids, including fatty acids, are being studied as metabolomic indicators of cancerogenesis in liver tissues [35].

At early stages of liver cancer (0-A stages according to BCLC and stage I according to TNM classification), the diagnostic effectiveness of using different biological markers varies widely (Table 2).

Table 1

Phases of clinical testing of hepatocellular carcinoma biomarkers

\begin{tabular}{|c|c|c|}
\hline Phase & Stage of investigation & Purpose \\
\hline 1 & Preclinical testing & Search for candidate markers and theoretical grounding of their application \\
\hline$\|$ & Clinical analysis and validation & Testing for the possibility of using in clinical practice \\
\hline III & Retrospective analysis & $\begin{array}{l}\text { Assessment of the effectiveness of using a biomarker according to the data } \\
\text { of the retrospective studies }\end{array}$ \\
\hline IV & Prospective analysis & $\begin{array}{l}\text { Assessment of the effectiveness of using a biomarker at various stages of hepatocellular } \\
\text { carcinoma and with consideration of false result frequency according to the data } \\
\text { of the prospective studies }\end{array}$ \\
\hline V & $\begin{array}{l}\text { Assessment of the effectiveness of } \\
\text { diagnostic application in actual clinical } \\
\text { practice }\end{array}$ & $\begin{array}{l}\text { Analysis of the results of implementing a biomarker into clinical practice and their impact } \\
\text { on the reduction of the hepatocellular carcinoma prevalence and morbidity in different } \\
\text { countries and various ethnic groups }\end{array}$ \\
\hline
\end{tabular}

Table 2

Diagnostic value of identifying some biomarkers in the blood serum at early and very early stages of liver cancer development

\begin{tabular}{|c|c|c|c|c|c|}
\hline Biomarker & $\begin{array}{l}\text { The author suggested it } \\
\text { as a HCC biomarker }\end{array}$ & $\begin{array}{l}\text { Threshold value } \\
\text { (cut-off) }\end{array}$ & Sensitivity (\%) & Specificity (\%) & References \\
\hline Alpha-fetoprotein (AFP) & $\begin{array}{l}\text { lu.S. Tatarinov, } 1964 \\
\text { G.I. Abelev, } 1968\end{array}$ & $10.9-400.0 \mathrm{ng} / \mathrm{ml}$ & $45.0(24.0-66.0)$ & $88.0(76.0-100.0)$ & $\begin{array}{l}{[17,19} \\
36-42]\end{array}$ \\
\hline $\begin{array}{l}\text { Des-gamma carboxyprothrombin } \\
\text { (DCP, PIVKA-II) }\end{array}$ & $\begin{array}{l}\text { H.A. Liebman et al., } \\
1984\end{array}$ & $\begin{array}{c}7.5-10.0 \mathrm{ng} / \mathrm{ml} \\
40.0-200.0 \mathrm{mAU} / \mathrm{ml}\end{array}$ & $46.0(15.0-77.0)$ & $89.5(81.0-98.0)$ & $\begin{array}{l}{[14,17,} \\
43-48]\end{array}$ \\
\hline $\begin{array}{l}\text { Glycosylated L3 isoform of alpha- } \\
\text { fetoprotein (AFP-L3) }\end{array}$ & K. Taketa et al., 1990 & $5.0-15.0 \%$ & $36.5(28.0-45.0)$ & $93.5(90.0-97.0)$ & {$[17,49-52]$} \\
\hline Alpha-L-fucoidase (AFU) & M. Giardina et al., 1992 & $870.0 \mathrm{nmol} / \mathrm{L}$ & $81.9(81.7-82.0)$ & $70.5(70.0-71.0)$ & {$[39,53-56]$} \\
\hline
\end{tabular}




\begin{tabular}{|c|c|c|c|c|c|}
\hline Biomarker & $\begin{array}{l}\text { The author suggested it } \\
\text { as a HCC biomarker }\end{array}$ & $\begin{array}{l}\text { Threshold value } \\
\text { (cut-off) }\end{array}$ & Sensitivity (\%) & Specificity (\%) & References \\
\hline Glypican-3 (GPC3) & $\begin{array}{l}\text { H.S. Hsu et al., } 1997 \\
\text { M. Capurro et al., } 2003\end{array}$ & $\begin{array}{l}20.0-300.0 \mathrm{ng} / \mathrm{ml} \\
26.8-58.8 \mathrm{mAU} / \mathrm{ml}\end{array}$ & $44.1(22.0-66.2)$ & $86.6(75.0-98.2)$ & {$[22,57-64]$} \\
\hline Golgi protein 73 (GP73) & J.A. Marrero et al., 2005 & $7.0-15.0 \mathrm{ng} / \mathrm{ml}$ & $65.5(62.0-69.0)$ & $87.0(86.0-88.0)$ & {$[65-67]$} \\
\hline $\begin{array}{l}\text { Squamous carcinoma antigen } \\
\text { (SCCA) }\end{array}$ & G. Giannelli et al., 2005 & $0.12-3.8 \mathrm{ng} / \mathrm{ml}$ & $40.1(24.0-56.1)$ & $66.5(50.0-83.0)$ & [68-72] \\
\hline $\begin{array}{l}\text { Squamous carcinoma antigen } \\
\text { (SCCA) and immune complex } \\
\text { SCCA-lgM }\end{array}$ & L. Beneduce et al., 2005 & No data & $79.5(70.0-89.0)$ & $50.0(50.0)$ & [71-73] \\
\hline Osteopontin (OPN) & J. Kim et al., 2006 & $9.3-642.5 \mathrm{ng} / \mathrm{ml}$ & $79.0(61.0-97.0)$ & $77.5(55.0-100.0)$ & {$[38,46,74-77]$} \\
\hline Annexin A2 (Ann A2) & N.Y. Ji et al., 2009 & $17.3 \mathrm{ng} / \mu \mathrm{l}$ & $84.8(83.2-86.4)$ & $70.5(67.5-73.5)$ & {$[19,78-80]$} \\
\hline Higly sensitive AFP-L3 (hs-AFP-L3) & H. Toyoda et al., 2011 & $5.0 \%$ & $53.5(50.0-57.0)$ & $74.3(63.5-85.1)$ & {$[81,82]$} \\
\hline Dickkopf-related protein 1 (DKK-1) & E.K. Tung et al., 2012 & $1.01-2.15 \mathrm{ng} / \mathrm{ml}$ & $61.9(50.0-73.8)$ & $87.4(80.8-94.0)$ & {$[13,46,83-87]$} \\
\hline Receptor tyrosine kinase sAxl (AXL) & Y. Sun et al., 2013 & No data & $78.9(76.9-80.8)$ & 79.5 (66.7-92.3) & {$[19,79,88,89]$} \\
\hline $\begin{array}{l}\text { Heparin-binding growth factor } \\
\text { midkine (MDK) }\end{array}$ & W.-W. Zhu et al., 2013 & $0.387-0.654 \mathrm{ng} / \mathrm{ml}$ & $88.5(87.0-90.0)$ & No data & [90-92] \\
\hline $\begin{array}{l}\text { Minichromosome maintenance } \\
\text { protein } 6 \text { (MCM6) }\end{array}$ & T. Zheng et al., 2014 & No data & $71.4(71.4)$ & $86.2(86.2)$ & {$[19,93]$} \\
\hline Thioredoxin (TRX) & J. Li et al., 2015 & No data & $74.7(74.5-74.9)$ & $83.6(79.6-87.5)$ & {$[19,94]$} \\
\hline $\begin{array}{l}\text { Soluble urokinase plasminogen } \\
\text { activator receptor (suPAR) }\end{array}$ & A. Chounta et al., 2015 & $9.56 \mathrm{ng} / \mathrm{ml}$ & $76.0(76.0)$ & $90.4(90.4)$ & [95] \\
\hline
\end{tabular}

Alpha-fetoprotein (AFP). In spite of the fact that AFP has already been used in clinical practice for over 50 years, this biomarker remains most widely used to predict the development and monitor the efficacy of HCC treatment $[5,31,39,40]$. AFP represents a glycoprotein with a $70 \mathrm{kDa}$ molecular mass synthetized by endodermal cells of the fetal yolk sac and later by the embryonic hepatocytes [86].

Increase of the AFP level in the blood is observed in degenerative processes in the liver tissues and in various oncological diseases. The analysis of the literature assessing AFP as a HCC biomarker in patients with LC showed the range of Se and Sp from 41 to $65 \%$ and from 80 to $94 \%$, respectively [96, 97]. Monitoring of the AFP level may be used to predict HCC recurrence after the operative treatment [98]. Data of AFP and US findings taken separately show Se to be below $50 \%$ at an early $\mathrm{HCC}$ stage but their combined application improves Se to $65 \%[23,38]$.

In the regions with a high HCC prevalence, application of serological screening alone is permissible and justified [99]. There has been described a successful experienced of HCC screening in patients with chronic hepatitis B in Alaska when US examination was impossible [100]. As a result, HCC was detected in part of the patients at the operable stage and early medical aid was provided [100].

Alpha-fetoprotein is a specific marker not only for $\mathrm{HCC}$, its level rises in LC and tumors of the lungs, biliary tract, stomach, and pancreas $[13,39,98]$. Due to a low Se, the recent versions of European and American clinical recommendations excluded AFP identification from the diagnostic algorithm [19, 26, 40].

Glycosylated $L 3$ isoform of alpha-fetoprotein (AFP-L3). AFP exists in three glycosylated isoforms [5, 7], and each possesses different capability to bind with lectin (lens culinaris agglutinin, LCA): AFP-L1 (nonLCA-bound fraction), AFP-L2 (weakly bound fraction), and AFP-L3 (LCA-bound fraction). AFP-L1 increases in chronic hepatitis and LC, whereas the elevation of AFP-L3 level is noted in tumor processes in the liver $[17,86]$. Predominance of AFP-L3 in the total AFP level by more than $10-15 \%$ allows HCC to be suspected at an early stage of its development. A large multicenter prospective study [101] showed that Sp of AFP-L3 is approximately $92 \%$, whereas Se is only about $37 \%$ irrespectively of the HCC stage.

A wide use of this biomarker is limited in clinical practice because the separation of the total AFP into fractions is possible only if its level exceeds $30 \mathrm{ng} /$ $\mathrm{ml}$ [99]. Therefore, tumors producing no AFP cannot be detected by this method [23]. To overcome this disadvantage, a highly sensitive assay (hs-AFP-L3) has been developed in Japan which is applicable at low values of total AFP in the blood [82].

Des-gamma carboxyprothrombin (DCP, PIVKA-II). DCP is an abnormal form of prothrombin which is expressed due to the defect of post-translational carboxylation with underlying vitamin $\mathrm{K}$ deficit [102]. The other name of this oncomarker is a protein induced by 
vitamin $\mathrm{K}$ absence (PIVKA II). Functionally, DCP is a pathological inactive prothrombin [103]. Application of this biomarker with a diagnostic purpose showed good results in Eastern Asia, North America, China [104-106]. In Europe, the results were more controversial as its level was established to depend on the race and etiology of $\mathrm{HCC}[17,48,105,106]$.

Des-gamma carboxyprothrombin may be used to assess not only the risk of HCC development but to predict its recurrence after surgical treatment. In the prospective study [107], application of DCP with AFP made it possible to suspect HCC 2 years before the diagnose verification. Further investigations are necessary in order to evaluate the effectiveness of this marker combination in the diagnosis of HCC [44]. It should be also kept in mind that DCP was mainly studied in Asian countries while the experience of using it in Europe remains insufficient.

Alpha-L-fucosidase (AFU). AFU is a lysosomal enzyme which breaks down glycoconjugates containing a carbohydrate - fructose [54]. Its activity has been shown to be higher in patients with HCC than with chronic hepatitis and healthy individuals [56, 108]. Application of AFU for screening purposes is not perspective due to a low Sp [109]. A high activity of this enzyme is found not only in HCC patients but in people with diabetes, pancreatitis, hypothyroidism as well [53, 109]. Besides, an average level of the enzyme activity depends on the person's race and ethnic predisposition [53]. The AFU level has been reported to elevate in $85 \%$ of patients who 6 months later were diagnosed HCC on the basis of US findings $[13,110]$. In its combination with AFP, Se increased to $95 \%$ and Sp to $99 \%$ during examination of HCC patients including those with advanced stage IV $[55,56]$.

Glypican-3 (GPC3). GPC3 belongs to a family of glypicans-proteoglycans. GPC3 is bound to the cellular membrane with a glycosyl-phosphatidyl-inositol anchor $[3,63]$. GPC3 interacts with some growth factors [22, $63,86]$ participating in cell proliferation and inhibition of cancer cell growth which characterizes it as an oncosuppressor [62, 63, 86]. An elevated GPC level is revealed in $50-55 \%$ of $\mathrm{HCC}$ patients [61] and only in $5 \%$ of those with LC $[22,63,111]$. At an early HCC stage ( 0 and $A$ according to BCLC or I according to TNM), Se and Sp of serum GPC3 identification were $55.1 \%$ (47.9$66.2 \%)$ and $97.0 \%$ (95.2-98.2\%), respectively [60].

An independent significance of the GPC3 for HCC diagnosis is restricted due to low Se [61, 86]. GPC3 is increased in $1 / 3$ of patients with normal AFP indices in the blood [64]. Absence of correlation between these biomarkers gives grounds for their combined use $[59,77]$, improving Se to $76 \%$ for the tumors below $3 \mathrm{~cm}$ in size $[64,112]$. GPC3 is determined immunohistochemically in liver bioptates which are used in clinics for differential diagnosis of HCC and other liver damages [13, 113].

Golgi protein 73 (GP73). GP73 is a specific membrane protein of Golgi complex which is usually expressed in the epithelial cells of different organs [114]. In the liver, it is synthesized mainly in the epithelium of the biliary tracts but when an inflammatory process develops its level in hepatocytes rises sharply $[38,86$, $114,115]$. HCC is also accompanied by GP73 increase in the blood [13, 54, 86, 116]. GP73 is more sensitive than AFP and the elevation of its level concurrently with HCC formation begins earlier [67, 70]. GP73 level does not depend on the etiological causes of tumor development, the stage of cancerogenesis, or functional state of the liver, however, it, like many other biomarkers, does not show high Sp. GP73 rises in other liver tumors as well including cholangiocarcinoma [67, 114]. Another drawback of practical application of this biomarker is a considerable inaccuracy in identification of this protein at low concentrations in the blood [54]. If combined with other markers, e.g. with AFP and AFP-L3, the diagnostic value of GP73 increases [87, 116, 117].

Squamous carcinoma antigen (SCCA) and immune complex SCCA-IgM. SCCA antigen is a member of the family of high-molecular serine protease inhibitors which is present in squamous epithelium $[5,72$, 86]. SCCA is synthesized in a large amount in epithelial tumors including cervix cancer cells. Giannelli et al. [69] have found a higher SCCA level in HCC patients relative to those suffering from $L C$. The identification of SCCA showed high Se but low Sp [71, 72]. The possibility of detecting SCCA in histological sections of tumor bioptates allowed it to be recommended as an immunohistochemical marker [118]. Guido et al. [119] have found that SCCA expression in neoplastic nodes is much higher than in regenerative ones.

The application of the immune complex SCCA-IgM rather than SCCA itself became an alternative variant. This complex is present normally in the desquamating epithelium and is not determined in the blood [54]. SCCA detection in the structure of the immune complex turned out to be more effective than identification of a free antigen [71, 118]. The frequency of SCCA-IgM identification in patients with chronic hepatitis, LC, and HCC was 18,26 , and $70 \%$, respectively $[54,120]$ but $\mathrm{Sp}$ remained sufficiently low (50\%) [71]. Evidently, these HCC markers will not have an independent value but their application in future as supplementary indicators in combination with some highly specific component is not excluded [72, 118].

Osteopontin (OPN). OPN, also known as transformed protein phosphatase (SPP1), represents an integrin-binding glycophosphoprotein which is produced in increased amount in many types of malignant neoplasms including cancer of the lungs, breast, intestine, pancreas, kidneys, gallbladder, prostate, ovaries [121-123]. In the physiological state, OPN is synthetized in the epithelium of biliary ducts, Kupffer cells but is not expressed in hepatocytes [35]. In 1999, an increased OPN production was found in the focus of hepatocyte necrosis caused by carbon 
tetrachloride. Later, the elevated OPN was reported in many diseases of the liver such as viral hepatitis, acute liver insufficiency, non-alcoholic and alcoholic fatty liver disease [13, 76, 123]. Its key role has been suggested in the induction of inflammation and fibrosis of the liver. Thus, spontaneous liver fibrosis develops during a year in transgenic mice with OPN hyperproduction [123, 124]. Kim et al. [74] were among the first to assess the value of OPN in HCC. The OPN level rises long before (from 6 months to several years) the episode of the instrumental detection of HCC and has better Se than AFP [121, 125].

There is no correlation between the content of OPN and AFP in HCC patients, therefore, their combination is considered as a variant of an effective predictor of HCC risk development [41, 122, 126].

Annexin A2 (Ann A2). Ann A2 is a calciumdependent protein binding phospholipids [19, 127]. It is expressed in the cells of different tissue tumors and plays a role in realization of the following processes: angiogenesis, proliferation, apoptosis, adhesion, invasion, cell migration [19, 128-131]. Its level changes in the variety of cancers such as cancer of the intestine, lungs, stomach, breast, esophagus [19, 33, 80]. Sun et al. [79] have observed the elevation of Ann A2 level in $83.2 \%$ cases in patients with $\mathrm{HCC}$ at 0 and $\mathrm{A}$ stages (BCLC classification) though $\mathrm{Sp}$ of this marker turned out to be low and did not exceed $67.5 \%$. A combination of Ann A2 and AFP slightly improved Se but did not influence Sp (87.4 and 68.3\%, respectively) [79]. In the HCC cohort producing no AFP, the Ann A2 level was elevated in $78.4 \%$ of cases. In this regard, Ann A2 is considered as a candidate biomarker for early HCC detection in patients with normal AFP indices in the blood serum [5, 33, 79, 80].

Dickkopf-related protein 1 (DKK-1). This is a secreted glycoprotein, inhibitor of intracellular betacatenin signaling pathway [132, 133]. It participates in cell proliferation, differentiation, and apoptosis [3]. Increase of its content in the blood was found in oncological processes of various localization: cancer of the prostate, skin, liver [86, 134]. It shows a low Se level (65\%) during HCC diagnosing but acceptable Sp (94\%). Therefore, at early stages of HCC, identification of DKK1 is more effective than AFP $[13,46,87,133]$. A combined use of AFP, DKK1, and DCP has been reported [87]. It increases Se and, consequently, the effectiveness of diagnosis of small-sized HCC [77, 87, 134].

Receptor tyrosine kinase sAxI (AXL). AXL is a tyrosine kinase which is involved in proliferation processes. It is expressed in many types of cells and its biological effects depend on the tissue specificity of the cells. An AXL form circulating in the blood has a molecular mass of $80 \mathrm{kDa}$ and can be detected by the standard diagnostic methods [135, 136]. Functionally, AXL makes cancer cells resistant to chemopreparations [137-139]. Its increased production is observed in oncological diseases and correlates with poor prognosis $[19,89,138-140]$. In a large multicenter study, a diagnostic value of $A X L$ for early $\mathrm{HCC}$ detection has been determined. AXL Se was found to be much higher than that of AFP [88]. A combination of AXL with AFP enables the improvement of Se method and preservation of Sp level within $90 \%$ [88].

Heparin-binding growth factor midkine (MDK). MDK has a low molecular mass. In the physiological state, the highest MDK level is observed in the midgestation period which reflects the name of the protein, midkine (the middle of kinetics). The MDK level in the serum of healthy people does not usually exceed $0.5-0.6 \mathrm{ng} / \mathrm{ml}$ while in patients with malignant diseases it is substantially higher [141]. There has been described an elevated MDK expression in tumors of different tissues and organs such as neuroblastoma, glioblastoma, cancer of the thyroid gland, lungs, esophagus, stomach, and prostate $[141,142]$. In the investigation carried out on patients with HCC and LC, it has been established that MDK levels in the first cohort of patients were on average 5 times higher than in the second. The calculated Se for MDK was $90 \%$ and for AFP only $50 \%$ [141, 142].

Minichromosome maintenance protein 6 (MCM6). This is a component of a protein complex maintaining minichromosome. It takes part in the process of DNA replication during the S-phase of the cell cycle [143]. In a single work [93], a promising outlook of MCM6 application has been shown for early detection of HCC at a satisfactory Se level. However, the cohort of the examined patients in this study differed by clinical criteria from the cohort indicated in the BCLC classification, therefore the value of MCM6 for diagnosis of early and very early HCC stages remains unclear [93, 144, 145].

Thioredoxin (TRX). TRX represents thiol oxidoreductase which reduces disulfide bonds of the proteins. TRX is involved in the biological processes such as regulation of protein synthesis, apoptosis, and cell proliferation and provides protection against oxidative stress [146]. TRX expression is elevated in the tumor cells and its level correlates with the prognosis which has been shown in cancer of the lungs and colorectum [147, 148]. Li et al. [94] have reported the potential possibility of using TRX for early revealing of HCC. In this study, TRX Se and Sp (74.9 and 87.5\%, respectively) were higher than for AFP (68.6 and 75.2\%, respectively). A combination of TRX and AFP raises the effectiveness of HCC diagnosis (Se - 81.3\%; Sp 93.4\%; AUC - 0.889), therefore, their joint application is justified but requires more ample study [94, 149].

Soluble urokinase plasminogen activator receptor (suPAR). SuPar is a circulating form of the membrane protein - a receptor activator of urokinase-type plasmogen [95]. In 2015, suPAR was used to assess tumor progression and cancer metastasizing [79]. The suPAR level in the serum is elevated in patients suffering from cancer of the ovaries, colon, and HCC [79, 95]. In the prospective study [95], the occurrence of HCC in 267 patients with chronic hepatitis has been investigated 
for 7 years. This work showed the possibility of using this marker for HCC prediction at Se $76.0 \%$ and Sp $90.4 \%$. These results lead to the conclusion that suPAR possesses a certain potential as an early predictor of the risk of HCC development.

\section{Conclusion}

The search for hepatocellular carcinoma biomarkers on the basis of proteomics is intensively being carried out in the countries worldwide since the detection of this disease at its early stage substantially influences the results of operative treatment and patients' quality of life. An ideal biomarker of hepatocellular carcinoma must be applicable for screening and reach the level of Se and Sp exceeding 90\%. Besides, the methodology of investigation should be minimally invasive and economically grounded [5].

In order to reach this goal, the majority of current strategies make provision for the use of new molecules in combination with previously discovered $[5,19,29]$. It is important that these markers are not associated with each other and do not give diagnostic cross results $[5,31]$. Additionally, certain diagnostic algorithms and mathematical formulas are proposed for use combining quantitative results of identification of 2-4 markers and biochemical tests $[33,52,56,87,102,141]$. The diagnostic value of different algorithms and diagnostic scales continue to be assessed in the prospective clinical studies being performed [150-152]. Despite a positive experience of using this approach in Japan, China, Korea, and other countries with a high morbidity from hepatocellular carcinoma, the main limiting factor of its implementation in clinical practice has been until now the cost of the analysis which grows significantly when a combination of markers and the corresponding diagnostic algorithms pertaining to them are applied [153].

Study funding. The work was supported by the Federal Target Program of Research \& Development in Priority Areas with participation of research organizations and universities within the frames of the joint French-Russian PHC Kolmogorov project (agreement No.14.616.21.0098; unique project identifier RFMEFI61618X0098).

Conflicts of interests. The authors have no conflicts of interest to declare.

\section{References}

1. Siegel R., Naishadham D., Jemal A. Cancer statistics, 2013. CA Cancer J Clin 2013; 63(1): 11-30, https://doi. org/10.3322/caac.21166.

2. Forner A., Llovet J.M., Bruix J. Hepatocellular carcinoma. Lancet 2012; 379(9822): 1245-1255, https://doi. org/10.1016/s0140-6736(11)61347-0.

3. Scaggiante B., Kazemi M., Pozzato G., Dapas B., Farra R., Grassi M., Zanconati F., Grassi G. Novel hepatocellular carcinoma molecules with prognostic and therapeutic potentials. World J Gastroenterol 2014; 20(5): 1268-1288, https://doi.org/10.3748/wjg.v20.i5.1268.

4. Bertuccio P., Turati F., Carioli G., Rodriguez T., La Vecchia C., Malvezzi M., Negri E. Global trends and predictions in hepatocellular carcinoma mortality. J Hepatol 2017; 67(2): 302-309, https://doi.org/10.1016/j. jhep.2017.03.011.

5. Tsuchiya N., Sawada Y., Endo I., Saito K., Uemura Y., Nakatsura T. Biomarkers for the early diagnosis of hepatocellular carcinoma. World J Gastroenterol 2015; 21(37): 10573, https://doi.org/10.3748/wjg.v21.i37.10573.

6. Duarte-Salles T., Misra S., Stepien M., Plymoth A., Muller D., Overvad K., Olsen A., Tjønneland A., Baglietto L., Severi G., Boutron-Ruault M.C., Turzanski-Fortner R., Kaaks R., Boeing H., Aleksandrova K., Trichopoulou A., Lagiou P., Bamia C., Pala V., Palli D., Mattiello A., Tumino R., Naccarati A., Bueno-de-Mesquita H.B., Peeters P.H., Weiderpass E., Quirós J.R., Agudo A., Sánchez-Cantalejo E., Ardanaz E., Gavrila D., Dorronsoro M., Werner M., Hemmingsson O., Ohlsson B., Sjöberg K., Wareham N.J., Khaw K.T., Bradbury K.E., Gunter M.J., Cross A.J., Riboli E., Jenab M., Hainaut P., Beretta L. Circulating osteopontin and prediction of hepatocellular carcinoma development in a large European population. Cancer Prev Res (Phila) 2016; 9(9): 758-765, https://doi.org/10.1158/1940-6207.capr-15-0434.

7. Bruix J., Gores G.J., Mazzaferro V. Hepatocellular carcinoma: clinical frontiers and perspectives. Gut 2014; 63(5): 844-855, https://doi.org/10.1136/gutjnl-2013-306627.

8. World Cancer Report 2014. Edited by Stewart B.W., Wild C. Lyon, France: International Agency for Research on Cancer; Geneva, Switzerland: WHO Press; 2014.

9. Torre L.A., Bray F., Siegel R.L., Ferlay J., LortetTieulent J., Jemal A. Global cancer statistics, 2012. CA Cancer J Clin 2015; 65(2): 87-108, https://doi.org/10.3322/ caac. 21262.

10. Rowe J., Ghouri Y., Mian I. Review of hepatocellular carcinoma: epidemiology, etiology, and carcinogenesis. J Carcinog 2017; 16(1): 1, https://doi.org/10.4103/jcar. jcar_9_16.

11. Ozakyol A. Global epidemiology of hepatocellular carcinoma (HCC epidemiology). J Gastrointest Cancer 2017; 48(3): 238-240, https://doi.org/10.1007/s12029-017-9959-0.

12. Breder V.V., Kosyrev V.Y., Kudashkin N.E., Laktionov K.K. Hepatocellular carcinoma as a social and medical problem in the Russian Federation. Medicinskij sovet 2016; 10: 10-18, https://doi.org/10.21518/2079701x-2016-10-10-18.

13. Chávez-López M.G., Zúñiga-García V., PérezCarreón J.I., Avalos-Fuentes A., Escobar Y., Camacho J. Eag1 channels as potential early-stage biomarkers of hepatocellular carcinoma. Biologics 2016; 10: 139-148, https://doi. org/10.2147/btt.s87402.

14. Ette A.I., Ndububa D.A., Adekanle O., Ekrikpo U. Diagnostic utility of alpha-fetoprotein and des-gammacarboxyprothrombin in nigerians with hepatocellular carcinoma. Niger J Clin Pract 2017; 20(10): 1267-1272, https://doi. org/10.4103/njcp.njcp_398_16.

15. Kiriienko V.T., Zaitsev I.A., Hrushkevych V.V., Potii V.V. Screening and early diagnosis of hepatocellular carcinoma. Aktual'naa infektologia 2018; 6(2): 70-76, https://doi. org/10.22141/2312-413x.6.2.2018.131091.

16. Durand F., Antoine C., Soubrane O. Liver 
transplantation in France. Liver Transp/ 2019; 25(5): 763-770, https://doi.org/10.1002/lt.25419.

17. Bertino G., Ardiri A., Malaguarnera M., Malaguarnera G., Bertino N., Calvagno G.S. Hepatocellualar carcinoma serum markers. Semin Oncol 2012; 39(4): 410-433, https://doi. org/10.1053/j.seminoncol.2012.05.001.

18. Singal A.G., Pillai A., Tiro J. Early detection, curative treatment, and survival rates for hepatocellular carcinoma surveillance in patients with cirrhosis: a meta-analysis. PLoS Med 2014; 11(4): e1001624, https://doi.org/10.1371/journal. pmed.1001624.

19. Reichl P., Mikulits W. Accuracy of novel diagnostic biomarkers for hepatocellular carcinoma: an update for clinicians (review). Oncol Rep 2016; 36(2): 613-625, https:// doi.org/10.3892/or.2016.4842.

20. Singal A.G., Mittal S., Yerokun O.A., Ahn C., Marrero J.A., Yopp A.C., Parikh N.D., Scaglione S.J. Hepatocellular carcinoma screening associated with early tumor detection and improved survival among patients with cirrhosis in the US. Am J Med 2017; 130(9): 1099-1106, https://doi.org/10.1016/j.amjmed.2017.01.021.

21. White D.L., Thrift A.P., Kanwal F., Davila J., El-Serag H.B. Incidence of hepatocellular carcinoma in all 50 United States, from 2000 through 2012. Gastroenterology 2017; 152(4): 812-820, https://doi.org/10.1053/j.gastro.2016.11.020.

22. Montalbano M., Rastellini C., McGuire J.T., Prajapati J., Shirafkan A., Vento R., Cicalese L. Role of glypican-3 in the growth, migration and invasion of primary hepatocytes isolated from patients with hepatocellular carcinoma. Cell Oncol (Dordr) 2018; 41(2): 169-184, https://doi.org/10.1007/s13402-0170364-2.

23. Abdel-Rahman O., Cheung W.Y. Population-based assessment of the national comprehensive cancer network recommendations for baseline imaging of hepatocellular carcinoma. Med Oncol 2019; 36(3): 26, https://doi.org/10.1007/ s12032-019-1248-2.

24. Farvardin S., Patel J., Khambaty M., Yerokun O.A., Mok H., Tiro J.A., Yopp A.C., Parikh N.D., Marrero J.A., Singal A.G. Patient-reported barriers are associated with lower hepatocellular carcinoma surveillance rates in patients with cirrhosis. Hepatology 2017; 65(3): 875-884, https://doi. org/10.1002/hep.28770.

25. Simmons O., Fetzer D., Yokoo T., Marrero J.A., Yopp A., Kono Y., Parikh N.D., Browning T., Singal A.G. Predictors of adequate ultrasound quality for hepatocellular carcinoma surveillance in patients with cirrhosis. Aliment Pharmacol Ther 2017; 45(1): 169-177, https://doi. org/10.1111/apt.13841.

26. Aubé C., Oberti F., Lonjon J., Pageaux G., Seror O., N'Kontchou G., Rode A., Radenne S., Cassinotto C., Vergniol J., Bricault I., Leroy V., Ronot M., Castera L., Michalak S., Esvan M., Vilgrain V.; CHIC Group. EASL and AASLD recommendations for the diagnosis of $\mathrm{HCC}$ to the test of daily practice. Liver Int 2017; 37(10): 1515-1525, https://doi. org/10.1111/liv.13429.

27. Ronot M., Fouque O., Esvan M., Lebigot J., Aubé C., Vilgrain V. Comparison of the accuracy of AASLD and LI-RADS criteria for the non-invasive diagnosis of HCC smaller than 3 cm. J Hepatol 2018; 68(4): 715-723, https://doi.org/10.1016/j. jhep.2017.12.014.

28. Masuzaki R., Karp S.J., Omata M. New serum markers of hepatocellular carcinoma. Semin Oncol 2012; 39(4): 434439, https://doi.org/10.1053/j.seminoncol.2012.05.009.
29. Sengupta S., Parikh N.D. Biomarker development for hepatocellular carcinoma early detection: current and future perspectives. Hepat Oncol 2017; 4(4): 111-122, https://doi. org/10.2217/hep-2017-0019.

30. She S., Xiang Y., Yang M., Ding X., Liu X., Ma L., Liu Q., Liu B., Lu Z., Li S., Liu Y., Ran X., Xu X., Hu H., Hu P., Zhang D., Ren H., Yang Y. C-reactive protein is a biomarker of AFP-negative HBV-related hepatocellular carcinoma. Int J Oncol 2015; 47(2): 543-554, https://doi.org/10.3892/ ijo.2015.3042.

31. Waidely E., Al-Yuobi A.R., Bashammakh A.S., ElShahawi M.S., Leblanc R.M. Serum protein biomarkers relevant to hepatocellular carcinoma and their detection. Analyst 2016; 141(1): 36-44, https://doi.org/10.1039/ c5an01884f.

32. Sia D., Llovet J.M. Liver cancer: translating '-omics' results into precision medicine for hepatocellular carcinoma. Nat Rev Gastroenterol Hepatol 2017; 14(10): 571-572, https:// doi.org/10.1038/nrgastro.2017.103.

33. Zhao S., Su G., Yang W., Yue P., Bai B., Lin Y., Zhang J., Ba Y., Luo Z., Liu X., Zhao L., Xie Y., Xu Y., Li S., Meng W., Xie X., Li X. Identification and comparison of differentiation-related proteins in hepatocellular carcinoma tissues by proteomics. Technol Cancer Res Treat 2017; 16(6): 1092-1101, https://doi.org/10.1177/1533034617732426.

34. Torres-Mena J.E., Salazar-Villegas K.N., SánchezRodríguez R., López-Gabiño B., Del Pozo-Yauner L., Arellanes-Robledo J., Villa-Treviño S., Gutiérrez-Nava M.A., Pérez-Carreón J.I. Aldo-keto reductases as early biomarkers of hepatocellular carcinoma: a comparison between animal models and human HCC. Dig Dis Sci 2018; 63(4): 934-944, https://doi.org/10.1007/s10620-018-4943-5.

35. Calvaruso V., Cabibbo G., Cacciola I., Petta S., Madonia S., Bellia A., Tinè F., Distefano M., Licata A., Giannitrapani L., Prestileo T., Mazzola G., Di Rosolini M.A., Larocca L., Bertino G., Digiacomo A., Benanti F., Guarneri L., Averna A., lacobello C., Magro A., Scalisi I., Cartabellotta F., Savalli F., Barbara M., Davì A., Russello M., Scifo G., Squadrito G., Cammà C., Raimondo G., Craxì A., Di Marco V.; Rete Sicilia Selezione Terapia-HCV (RESIST$\mathrm{HCV}$ ). Incidence of hepatocellular carcinoma in patients with HCV-associated cirrhosis treated with direct-acting antiviral agents. Gastroenterology 2018; 155(2): 411-421, https://doi. org/10.1053/j.gastro.2018.04.008.

36. Tatarinov lu.S. Detection of embryo-specific alphaglobulin in the blood serum of a patient with primary liver cancer. Voprosy meditsinskoi khimii 1964; 10: 90-91.

37. Abelev G.I. Production of embrional serum alphaglobulin by hepatomas: review of experimental and clinical data. Cancer Res 1968; 28(7): 1344-1350.

38. Rich N., Singal A.G. Hepatocellular carcinoma tumour markers: current role and expectations. Best Pract Res Clin Gastroenterol 2014; 28(5): 843-853, https://doi.org/10.1016/j. bpg.2014.07.018.

39. Bai D.S., Zhang C., Chen P., Jin S.J., Jiang G.Q. The prognostic correlation of AFP level at diagnosis with pathological grade, progression, and survival of patients with hepatocellular carcinoma. Sci Rep 2017; 7(1): 12870, https:// doi.org/10.1038/s41598-017-12834-1.

40. Gao J., Song P. Combination of triple biomarkers AFP, AFP-L3, and PIVAKII for early detection of hepatocellular carcinoma in China: expectation. Drug Discov Ther 2017; 11(3): 168-169, https://doi.org/10.5582/ddt.2017.01036. 
41. Li J., Chen X., Dai M., Huang S., Chen J., Dai S. Diagnostic accuracy of osteopontin plus alpha-fetoprotein in the hepatocellular carcinoma: a meta-analysis. Clin Res Hepatol Gastroenterol 2017; 41(5): 543-553, https://doi. org/10.1016/j.clinre.2017.01.010.

42. Shen Q., Eun J.W., Lee K., Kim H.S., Yang H.D., Kim S.Y., Lee E.K., Kim T., Kang K., Kim S., Min D.H., Oh S.N., Lee Y.J., Moon H., Ro S.W., Park W.S., Lee J.Y., Nam S.W. Barrier to autointegration factor 1, procollagenlysine, 2-oxoglutarate 5-dioxygenase 3 , and splicing factor $3 \mathrm{~b}$ subunit 4 as early-stage cancer decision markers and drivers of hepatocellular carcinoma. Hepatology 2018; 67(4): 13601377, https://doi.org/10.1002/hep.29606.

43. Liebman H.A., Furie B.C., Tong M.J., Blanchard R.A., Lo K.J., Lee S.D., Coleman M.S., Furie B. Desgamma-carboxy (abnormal) prothrombin as a serum marker of primary hepatocellular carcinoma. $N$ Engl $J$ Med 1984; 310: 1427-1431, https://doi.org/10.1056/ nejm198405313102204.

44. Poté N., Cauchy F., Albuquerque M., Voitot H., Belghiti J., Castera L., Puy H., Bedossa P., Paradis V. Performance of PIVKA-II for early hepatocellular carcinoma diagnosis and prediction of microvascular invasion. J Hepatol 2015; 62(4): 848-854, https://doi.org/10.1016/j. jhep.2014.11.005.

45. Haque S., Kumari R., Muzaffar A., Kumar U., Sharan A., Kumari B. Estimation of serum alpha feto-protein (AFP), interlukin-6 and des-y-carboxyprothrombin (DCP) in case of hepatocellular carcinoma. Bangladesh Journal of Medical Science 2016; 15(2): 230-233, https://doi.org/10.3329/bjms. v15i2.19602.

46. Jang E.S., Jeong S.-H., Kim J.-W., Choi Y.S., Leissner P., Brechot C. Diagnostic performance of alphafetoprotein, protein induced by vitamin $\mathrm{K}$ absence, osteopontin, dickkopf-1 and its combinations for hepatocellular carcinoma. PLoS One 2016; 11(3): e0151069, https://doi.org/10.1371/ journal.pone.0151069.

47. Chen J., Wu G., Li Y. Evaluation of serum desgamma-carboxy prothrombin for the diagnosis of hepatitis virus-related hepatocellular carcinoma: a metaanalysis. Dis Markers 2018 4; 2018; 8906023, https://doi. org/10.1155/2018/8906023.

48. Svobodova S., Karlikova M., Topolcan O., Pecen L., Pestova M., Kott O., Treska V., Slouka D., Kucera R. PIVKA-II as a potential new biomarker for hepatocellular carcinoma a pilot study. In Vivo 2018; 32(6): 1551-1554, https://doi. org/10.21873/invivo.11413.

49. Taketa K., Sekiya C., Namiki M., Akamatsu K., Ohta Y., Endo Y., Kosaka K. Lectin-reactive profiles of alphafetoprotein characterizing hepatocellular carcinoma and related conditions. Gastroenterology 1990; 99(2): 508-518, https://doi. org/10.1016/0016-5085(90)91034-4.

50. Taketa K., Endo Y., Sekiya C., Tanikawa K., Koji T., Taga H., Satomura S., Matsuura S., Kawai T., Hirai H. A collaborative study for the evaluation of lectin-reactive a-fetoproteins in early detection of hepatocellular carcinoma. Cancer Res 1993; 53(22): 5419-5423.

51. Marrero J.A., Feng Z., Wang Y., Nguyen M.H., Befeler A.S., Roberts L.R., Reddy K.R., Harnois D., Llovet J.M., Normolle D., Dalhgren J., Chia D., Lok A.S., Wagner P.D., Srivastava S., Schwartz M. Alpha-fetoprotein, des-gamma carboxyprothrombin, and lectin-bound alpha-fetoprotein in early hepatocellular carcinoma.
Gastroenterology 2009; 137(1): 110-118, https://doi. org/10.1053/j.gastro.2009.04.005.

52. Park S.J., Jang J.Y., Jeong S.W., Cho Y.K., Lee S.H., Kim S.G., Cha S.W., Kim Y.S., Cho Y.D., Kim H.S., Kim B.S., Park S., Bang H.I. Usefulness of AFP, AFP-L3, and PIVKA-II, and their combinations in diagnosing hepatocellular carcinoma. Medicine (Baltimore) 2017; 96(11): e5811, https://doi. org/10.1097/md.0000000000005811.

53. Giardina M., Matarazzo M., Varriale A., Morante R., Napoli A., Martino R. Serum alpha-L-fucosidase. A useful marker in the diagnosis of hepatocellular carcinoma. Cancer 1992; 70(5): 1044-1048, https://doi.org/10.1002/10970142(19920901)70:5<1044::aid-cncr2820700506>3.0.co;2-u.

54. Sergeev M.N., Shevaldin A.G., Rakhmanova A.G., Sleptsova S.S., Lyashenko E.A., Sharoyko V.V. Molecular markers of hepatocellular carcinoma. perspectives of early diagnostics. VICh-infektsiya i immunosupressii 2014; 6(3): $16-23$.

55. Trevisani F., D'Intino P.E., Morselli-Labate A.M., Mazzella G., Accogli E., Caraceni P., Domenicali M., De Notariis S., Roda E., Bernardi M. Serum alpha-fetoprotein for diagnosis of hepatocellular carcinoma in patients with chronic liver disease: influence of $\mathrm{HBsAg}$ and anti-HCV status. J Hepatol 2001; 34(4): 570-575, https://doi.org/10.1016/s01688278(00)00053-2.

56. Junna Z., Gongde C., Jinying X., Xiu Z. Serum AFU, 5'-NT and AFP as biomarkers for primary hepatocellular carcinoma diagnosis. Open Med (Wars) 2017; 12(1): 354-358, https://doi.org/10.1515/med-2017-0051.

57. Hsu H.C., Cheng W., Lai P.L. Cloning and expression of a developmentally regulated transcript MXR7 in hepatocellular carcinoma: biological significance and temporospatial distribution. Cancer Res 1997; 57(22): 5179-5184.

58. Capurro M., Wanless I.R., Sherman M., Deboer G., Shi W., Miyoshi E., Filmus J. Glypican-3: a novel serum and histochemical marker for hepatocellular carcinoma. Gastroenterology 2003; 125(1): 89-97, https://doi.org/10.1016/ s0016-5085(03)00689-9.

59. Qiao S.S., Cui Z.Q., Gong L., Han H., Chen P.C., Guo L.M., Yu X., Wei Y.H., Ha S.A., Kim J.W., Jin Z.T., Li S., Peng J.R., Leng X.S. Simultaneous measurements of serum AFP, GPC-3 and HCCR for diagnosing hepatocellular carcinoma. Hepatogastroenterology 2011; 58(110-111): 17181724, https://doi.org/10.5754/hge11124.

60. Tangkijvanich P., Chanmee T., Komtong S., Mahachai V., Wisedopas N., Pothacharoen P., Kongtawelert P. Diagnostic role of serum glypican-3 in differentiating hepatocellular carcinoma from non-malignant chronic liver disease and other liver cancers. J Gastroenterol Hepatol 2010; 25(1): 129-137, https://doi.org/10.1111/j.1440-1746.2009.05988.X.

61. Jia X., Liu J., Gao Y., Huang Y., Du Z. Diagnosis accuracy of serum glypican-3 in patients with hepatocellular carcinoma: a systematic review with meta-analysis. Arch Med Res 2014; 45(7): 580-588, https://doi.org/10.1016/j. arcmed.2014.11.002.

62. Haruyama Y., Kataoka H. Glypican-3 is a prognostic factor and an immunotherapeutic target in hepatocellular carcinoma. World J Gastroenterol 2016; 22(1): 275-283, https://doi.org/10.3748/wjg.v22.i1.275.

63. Montalbano M., Georgiadis J., Masterson A.L., McGuire J.T., Prajapati J., Shirafkan A., Rastellini C., Cicalese L. Biology and function of glypican-3 as a candidate for early cancerous transformation of hepatocytes in 
hepatocellular carcinoma (review). Oncol Rep 2017; 37(3): 1291-1300, https://doi.org/10.3892/or.2017.5387.

64. Xu D., Su C., Sun L., Gao Y., Li Y. Performance of serum glypican 3 in diagnosis of hepatocellular carcinoma: a meta-analysis. Ann Hepatol 2018; 18(1): 58-67, https://doi. org/10.5604/01.3001.0012.7863.

65. Marrero J.A., Romano P.R., Nikolaeva O., Steel L., Mehta A., Fimmel C.J., Comunale M.A., D’Amelio A., Lok A.S., Block T.M. GP73, a resident Golgi glycoprotein, is a novel serum marker for hepatocellular carcinoma. J Hepatol 2005; 43(6): 1007-1012, https://doi.org/10.1016/j.jhep.2005.05.028.

66. Hu J.S., Wu D.W., Liang S., Miao X.Y. GP73, a resident Golgi glycoprotein, is sensibility and specificity for hepatocellular carcinoma of diagnosis in a hepatitis B-endemic Asian population. Med Oncol 2010; 27(2): 339-345, https://doi. org/10.1007/s12032-009-9215-y.

67. Jiao C., Cui L., Piao J., Qi Y., Yu Z. Clinical significance and expression of serum Golgi protein 73 in primary hepatocellular carcinoma. J Cancer Res Ther 2018; 14(6): 1239-1244, https://doi.org/10.4103/0973-1482.199784.

68. Giannelli G., Marinosci F., Trerotoli P., Volpe A., Quaranta M., Dentico P., Antonaci S. SCCA antigen combined with alpha-fetoprotein as serologic markers of HCC. Int J Cancer 2005; 117(3): 506-509, https://doi.org/10.1002/ijc.21189.

69. Giannelli G., Fransvea E., Trerotoli P., Beaugrand M., Marinosci F., Lupo L., Nkontchou G., Dentico P., Antonaci S. Clinical validation of combined serological biomarkers for improved hepatocellular carcinoma diagnosis in 961 patients. Clin Chim Acta 2007; 383(1-2): 147-152, https://doi. org/10.1016/j.cca.2007.05.014.

70. Witjes C.D., van Aalten S.M., Steyerberg E.W., Borsboom G.J., de Man R.A., Verhoef C., Ijzermans J.N. Recently introduced biomarkers for screening of hepatocellular carcinoma: a systematic review and metaanalysis. Hepatol Int 2013; 7(1): 59-64, https://doi. org/10.1007/s12072-012-9374-3.

71. Pozzan C., Cardin R., Piciocchi M., Cazzagon N., Maddalo G., Vanin V., Giacomin A., Pontisso P., Cillo U., Farinati F. Diagnostic and prognostic role of SCCA-IgM serum levels in hepatocellular carcinoma (HCC). J Gastroenterol Hepatol 2014; 29(8): 1637-1644, https://doi.org/10.1111/ jgh.12576.

72. Liu C.H., Gil-Gómez A., Ampuero J., Romero-Gómez M. Diagnostic accuracy of SCCA and SCCA-IgM for hepatocellular carcinoma: a meta-analysis. Liver Int 2018; 38(10): 18201831, https://doi.org/10.1111/liv.13867.

73. Beneduce L., Castaldi F., Marino M., Quarta S., Ruvoletto M., Benvegnù L., Calabrese F., Gatta A., Pontisso P., Fassina G. Squamouse cell carcinoma antigenimmunoglobulin $M$ complexes as novel biomarkers for hepatocellular carcinoma. Cancer 2005; 103(12): 2558-2565, https://doi.org/10.1002/cncr.21106.

74. Kim J., Ki S.S., Lee S.D., Han C.J., Kim Y.C., Park S.H., Cho S.Y., Hong Y.J., Park H.Y., Lee M., Jung H.H., Lee K.H., Jeong S.H. Elevated plasma osteopontin levels in patients with hepatocellular carcinoma. Am J Gastroenterol 2006; 101(9): 2051-2059, https://doi.org/10.1111/j.15720241.2006.00679.x.

75. Shang S., Plymoth A., Ge S., Feng Z., Rosen H.R., Sangrajrang S., Hainaut P., Marrero J.A., Beretta L. Identification of osteopontin as a novel marker for early hepatocellular carcinoma. Hepatology 2012; 55(2): 483-490, https://doi.org/10.1002/hep.24703.
76. Wan H.G., Xu H., Gu Y.M., Wang H., Xu W., Zu M.H. Comparison osteopontin vs AFP for the diagnosis of HCC: a meta-analysis. Clin Res Hepatol Gastroenterol 2014; 38(6): 706-714, https://doi.org/10.1016/j.clinre.2014.06.008.

77. Ge T., Shen Q., Wang N., Zhang Y., Ge Z., Chu W., Lv X., Zhao F., Zhao W., Fan J., Qin W. Diagnostic values of alpha-fetoprotein, dickkopf-1, and osteopontin for hepatocellular carcinoma. Med Oncol 2015; 32(3): 59, https:// doi.org/10.1007/s12032-014-0367-z.

78. Ji N.Y., Park M.Y., Kang Y.H., Lee C.I., Kim D.G., Yeom Y.I., Jang Y.J., Myung P.K., Kim J.W., Lee H.G., Kim J.W., Lee K., Song E.Y. Evaluation of annexin II as a potential serum marker for hepatocellular carcinoma using a developed sandwich ELISA method. Int J Mol Med 2009; 24(6): 765-771, https://doi.org/10.3892/ijmm_00000290.

79. Sun Y., Gao G., Cai J., Wang Y., Qu X., He L., Liu F., Zhang Y., Lin K., Ma S., Yang X., Qian X., Zhao X. Annexin A2 is a discriminative serological candidate in early hepatocellular carcinoma. Carcinogenesis 2013; 34(3): 595-604, https://doi. org/10.1093/carcin/bgs372.

80. Shaker M.K., Abdel Fattah H.I., Sabbour G.S., Montasser I.F., Abdelhakam S.M., El Hadidy E., Yousry R., El Dorry A.K. Annexin A2 as a biomarker for hepatocellular carcinoma in Egyptian patients. World J Hepatol 2017; 9(9): 469-476, https://doi.org/10.4254/wjh.v9.i9.469.

81. Toyoda H., Kumada T., Tada T., Kaneoka Y., Maeda A., Kanke F., Satomura S. Clinical utility of highly sensitive lens culinaris agglutinin-reactive alpha-fetoprotein in hepatocellular carcinoma patients with alpha-fetoprotein $<20 \mathrm{ng} / \mathrm{ml}$. Cancer Sci 2011; 102(5): 1025-1031, https://doi.org/10.1111/j.13497006.2011.01875.x.

82. Oda K., Ido A., Tamai T., Matsushita M., Kumagai K., Mawatari S., Saishoji A., Kure T., Ohno K., Toyokura E., Imanaka D., Moriuchi A., Uto H., Oketani M., Hashiguchi T., Tsubouchi $H$. Highly sensitive lens culinaris agglutininreactive a-fetoprotein is useful for early detection of hepatocellular carcinoma in patients with chronic liver disease. Oncol Rep 2011; 26(5): 1227-1233, https://doi. org/10.3892/or.2011.1425.

83. Tung E.K., Ng I.O. Significance of serum DKK1 as a diagnostic biomarker in hepatocellular carcinoma. Future Oncol 2012; 8(12): 1525-1528, https://doi.org/10.2217/fon.12.147.

84. Shen Q., Fan J., Yang X.R., Tan Y., Zhao W., Xu Y., Wang N., Niu Y., Wu Z., Zhou J., Qu S.J., Shi Y.H., Yu B., Tang N., Chu W., Wang M., Wu J., Zhang Z., Yang S., Gu J., Wang H., Qin W. Serum DKK1 as a protein biomarker for the diagnosis of hepatocellular carcinoma: a large-scale, multicentre study. Lancet Oncol 2012; 13(8): 817-826, https:// doi.org/10.1016/s1470-2045(12)70233-4.

85. Zhang J., Zhao Y., Yang Q. Sensitivity and specificity of dickkopf-1 protein in serum for diagnosing hepatocellular carcinoma: a meta-analysis. Int J Biol Markers 2014; 29(4): 403-410, https://doi.org/10.5301/jbm.5000101.

86. Van Hees S., Michielsen P., Vanwolleghem T. Circulating predictive and diagnostic biomarkers for hepatitis B virusassociated hepatocellular carcinoma. World J Gastroenterol 2016; 22(37): 8271-8282, https://doi.org/10.3748/wjg.v22. i37.8271.

87. Qin Q.F., Weng J., Xu G.X., Chen C.M., Jia C.K. Combination of serum tumor markers dickkopf-1, DCP and AFP for the diagnosis of primary hepatocellular carcinoma. Asian Pac J Trop Med 2017; 10(4): 409-413, https://doi. org/10.1016/j.apjtm.2017.03.016. 
88. Reichl P., Fang M., Starlinger P., Staufer K., Nenutil R., Muller P., Greplova K., Valik D., Dooley S., Brostjan C., Gruenberger T., Shen J., Man K., Trauner M., Yu J., Gao C.F., Mikulits W. Multicenter analysis of soluble Axl reveals diagnostic value for very early stage hepatocellular carcinoma. Int J Cancer 2015; 137(2): 385-394, https://doi.org/10.1002/ ijc.29394.

89. Dengler M., Staufer K., Huber H., Stauber R., Bantel H., Weiss K.H., Starlinger P., Pock H., Klöters-Plachky P., Gotthardt D.N., Rauch P., Lackner C., Stift J., Brostjan C., Gruenberger T., Kumada T., Toyoda H., Tada T., Weiss T.S., Trauner M., Mikulits W. Soluble Axl is an accurate biomarker of cirrhosis and hepatocellular carcinoma development: results from a large scale multicenter analysis. Oncotarget 2017; 8(28): 46234-46248, https://doi.org/10.18632/oncotarget.17598.

90. Zhu W.-W., Guo J.-J., Guo L., Jia H.L., Zhu M., Zhang J.B., Loffredo C.A., Forgues M., Huang H., Xing X.J., Ren N., Dong Q.Z., Zhou H.J., Ren Z.G., Zhao N.Q., Wang X.W., Tang Z.Y., Qin L.X., Ye Q.H. Evaluation of midkine as a diagnostic serum biomarker in hepatocellular carcinoma. Clin Cancer Res 2013; 19(14): 3944-3954, https://doi. org/10.1158/1078-0432.ccr-12-3363.

91. Shaheen K.Y., Abdel-Mageed A.I., Safwat E., AlBreedy A.M. The value of serum midkine level in diagnosis of hepatocellular carcinoma. Int J Hepatol 2015; 2015: 146389, https://doi.org/10.1155/2015/146389.

92. Vongsuvanh R., van Der Poorten D., Iseli T., Strasser S.I., McCaughan G.W., George J. Midkine increases diagnostic yield in AFP negative and NASH-related hepatocellular carcinoma. PLoS One 2016; 11(5): e0155800, https://doi.org/10.1371/journal.pone.0155800.

93. Zheng T., Chen M., Han S., Zhang L., Bai Y., Fang X., Ding S.Z., Yang Y. Plasma minichromosome maintenance complex component 6 is a novel biomarker for hepatocellular carcinoma patients. Hepatol Res 2014; 44(13): 1347-1356, https://doi.org/10.1111/hepr.12303.

94. Li J., Cheng Z.J., Liu Y., Yan Z.L., Wang K., Wu D., Wan X.Y., Xia Y., Lau W.Y., Wu M.C., Shen F. Serum thioredoxin is a diagnostic marker for hepatocellular carcinoma. Oncotarget 2015; 6(11): 9551-9563, https://doi.org/10.18632/ oncotarget.3314.

95. Chounta A., Ellinas C., Tzanetakou V., Pliarhopoulou F., Mplani V., Oikonomou A., Leventogiannis K., GiamarellosBourboulis E.J. Serum soluble urokinase plasminogen activator receptor as a screening test for the early diagnosis of hepatocellular carcinoma. Liver Int 2015; 35(2): 601-607, https://doi.org/10.1111/liv.12705.

96. Gupta S., Bent S., Kohlwes J. Test characteristics of alpha-fetoprotein for detecting hepatocellular carcinoma in patients with hepatitis C. A systematic review and critical analysis. Ann Intern Med 2003; 139(1): 46-50, https://doi. org/10.7326/0003-4819-139-1-200307010-00012.

97. Yang J.D., Dai J., Singal A.G., Gopal P., Addissie B.D., Nguyen M.H., Befeler A.S., Reddy K.R., Schwartz M., Harnois D.M., Yamada H., Gores G.J., Feng Z., Marrero J.A., Roberts L.R. Improved performance of serum alpha-fetoprotein for hepatocellular carcinoma diagnosis in HCV cirrhosis with normal alanine transaminase. Cancer Epidemiol Biomarkers Prev 2017; 26(7): 1085-1092, https://doi.org/10.1158/10559965.epi-16-0747.

98. Sauzay C., Petit A., Bourgeois A.M., Barbare J.C., Chauffert B., Galmiche A., Houessinon A. Alpha-foetoprotein (AFP): a multi-purpose marker in hepatocellular carcinoma.
Clin Chim Acta 2016; 463: 39-44, https://doi.org/10.1016/j. cca.2016.10.006.

99. Yen C.W., Kuo Y.H., Wang J.H., Chang K.C., Kee K.M., Hung S.F., Chen Y., Tsai L.S., Chen S.C., Hung C.H., Lu S.N. Did AFP-L3 save ultrasonography in community screening? Kaohsiung J Med Sci 2018; 34(10): 583-587, https://doi. org/10.1016/j.kjms.2018.05.005.

100. McMahon B.J., Bulkow L., Harpster A., Snowball M., Lanier A., Sacco F., Dunaway E., Williams J. Screening for hepatocellular carcinoma in Alaska natives infected with chronic hepatitis B: a 16-year population-based study. Hepatology 2000; 32(4 Pt 1): 842-846, https://doi.org/10.1053/ jhep.2000.17914.

101. Sterling R.K., Jeffers L., Gordon F., Venook A.P., Reddy K.R., Satomura S., Kanke F., Schwartz M.E., Sherman M. Utility of lens culinaris agglutinin-reactive fraction of alpha-fetoprotein and des-gamma-carboxy prothrombin, alone or in combination, as biomarkers for hepatocellular carcinoma. Clin Gastroenterol Hepatol 2009; 7(1): 104-113, https://doi.org/10.1016/j.cgh.2008.08.041.

102. Unić A., Derek L., Duvnjak M., Patrlj L., Rakić M., Kujundžić M., Renjić V., Štoković N., Dinjar P., Jukic A., Grgurević I. Diagnostic specificity and sensitivity of PIVKAII, GP3, CSTB, SCCA1 and HGF for the diagnosis of hepatocellular carcinoma in patients with alcoholic liver cirrhosis. Ann Clin Biochem 2018; 55(3): 355-362, https://doi. org/10.1177/0004563217726808.

103. Hemken P.M., Sokoll L.J., Yang X., Dai J., Elliott D., Gawel S.H., Lucht M., Feng Z., Marrero J.A., Srivastava S., Chan D.W., Davis G.J. Validation of a novel model for the early detection of hepatocellular carcinoma. Clin Proteomics 2019; 16: 2, https://doi.org/10.1186/s12014-018-9222-0.

104. Yamashiki N., Sugawara Y., Tamura S., Kaneko J., Yoshida H., Aoki T., Hasegawa K., Akahane M., Ohtomo K., Fukayama M., Koike K., Kokudo N. Diagnostic accuracy of alpha-fetoprotein and des-gamma-carboxy prothrombin in screening for hepatocellular carcinoma in liver transplant candidates. Hepatol Res 2011; 41(12): 1199-1207, https://doi. org/10.1111/j.1872-034x.2011.00871.x.

105. Best J., Bilgi H., Heider D., Schotten C., Manka P., Bedreli S., Gorray M., Ertle J., van Grunsven L.A., Dechene A. The GALAD scoring algorithm based on AFP, AFP-L3, and DCP significantly improves detection of BCLC early stage hepatocellular carcinoma. Z Gastroenterol 2016; 54(12): 12961305, https://doi.org/10.1055/s-0042-119529.

106. Wu J., Xiang Z., Bai L., He L., Tan L., Hu M., Ren Y. Diagnostic value of serum PIVKA-II levels for BCLC early hepatocellular carcinoma and correlation with HBV DNA. Cancer Biomark 2018; 23(2): 235-242, https://doi.org/10.3233/ cbm-181402.

107. Yu R., Tan Z., Xiang X., Dan Y., Deng G. Effectiveness of PIVKA-II in the detection of hepatocellular carcinoma based on real-world clinical data. BMC Cancer 2017; 17(1): 608, https://doi.org/10.1186/s12885-017-3609-6.

108. Shuang Z., Mao Y., Lin G., Wang J., Huang X., Chen J., Duan F., Li S. Alpha-L-fucosidase serves as a prognostic indicator for intrahepatic cholangiocarcinoma and inhibits its invasion capacity. Biomed Res Int 2018; 2018: 8182575, https://doi.org/10.1155/2018/8182575.

109. López Vivancos J., Segura R.M., Oliva G., Vives L., Pascual C., Vilaseca J. Value of the serum measurement of alpha-L-fucosidase in the diagnosis of hepatocarcinoma. Med Clin (Barc) 1989; 93(7): 241-243. 
110. Ishizuka H., Nakayama T., Matsuoka S., Gotoh I., Ogawa M., Suzuki K., Tanaka N., Tsubaki K., Ohkubo H., Arakawa Y., Okano T. Prediction of the development of hepato-cellular-carcinoma in patients with liver cirrhosis by the serial determinations of serum alpha-L-fucosidase activity. Intern Med 1999; 38(12): 927-931, https://doi.org/10.2169/ internalmedicine.38.927.

111. Gotoh M., Nakatani T., Masuda T., Mizuguchi Y., Sakamoto M., Tsuchiya R., Kato H., Furuta K. Prediction of invasive activities in hepatocellular carcinomas with special reference to alpha-fetoprotein and des-gammacarboxyprothrombin. Jpn J Clin Oncol 2003; 33(10): 522-526, https://doi.org/10.1093/jjco/hyg096.

112. Attallah A.M., El-Far M., Omran M.M., Abdelrazek M.A., Attallah A.A., Saeed A.M., Farid K. GPCHCC model: a combination of glybican-3 with other routine parameters improves the diagnostic efficacy in hepatocellular carcinoma. Tumor Biol 2016; 37(9): 12571-12577, https://doi. org/10.1007/s13277-016-5127-6.

113. Majeed S., Mushtaq S., Azam M., Akhtar N., Hussain M., Loya A. Diagnostic accuracy of glypican-3 in differentiating hepatocellular carcinoma from metastatic liver tumours. J Pak Med Assoc 2018; 68(7): 1029-1031.

114. Liang R., Liu Z., Piao X., Zuo M., Zhang J., Liu Z., Li Y., Lin Y. Research progress on GP73 in malignant tumors. Onco Targets Ther 2018; 11: 7417-7421, https://doi. org/10.2147/ott.s181239.

115. Ismail M.M., Morsi H.K., Abdulateef N.A., Noaman M.K., Abou El-Ella G.A. Evaluation of prothrombin induced by vitamin $\mathrm{K}$ absence, macrophage migration inhibitory factor and Golgi protein-73 versus alpha fetoprotein for hepatocellular carcinoma diagnosis and surveillance. Scand $J$ Clin Lab Invest 2017; 77(3): 175-183, https://doi.org/10.1080/ 00365513.2017 .1286684 .

116. Farag R.M.A., Al Ayobi D., Alsaleh K.A., Kwon H.J., EL-Ansary A., Dawoud E.A. Studying the impact of Golgi protein 73 serving as a candidate biomarker in early diagnosis for hepatocellular carcinoma among Saudi patients. Asian Pac J Cancer Prev 2019; 20(1): 215-220, https://doi.org/10.31557/ apjcp.2019.20.1.215.

117. Xu W.J., Guo B.L., Han Y.G., Shi L., Ma W.S. Diagnostic value of alpha-fetoprotein-L3 and Golgi protein 73 in hepatocellular carcinomas with low AFP levels. Tumor Biol 2014; 35(12): 12069-12074, https://doi.org/10.1007/s13277014-2506-8.

118. Guarino M., Di Costanzo G.G., Gallotta A., Tortora R., Paneghetti L., Auriemma F., Tuccillo C., Fassina G., Caporaso N., Morisco F. Circulating SCCA-IgM complex is a useful biomarker to predict the outcome of therapy in hepatocellular carcinoma patients. Scand J Clin Lab Invest 2017; 77(6): 448-453, https://doi.org/10.1080/00365513.2017. 1336569.

119. Guido M., Roskams T., Pontisso P., Fassan M., Thung S.N., Giacomelli L., Sergio A., Farinati F., Cillo U., Rugge M. Squamous cell carcinoma antigen in human liver carcinogenesis. J Clin Pathol 2008; 61(4): 445-447, https://doi. org/10.1136/jcp.2007.051383.

120. Anwar S.L., Lehmann U. MicroRNAs: emerging novel clinical biomarkers for hepatocellular carcinomas. J Clin Med 2015; 4(8): 1631-1650, https://doi.org/10.3390/jcm4081631.

121. Cabiati M., Gaggini M., Cesare M.M., Caselli C., De Simone P., Filipponi F., Basta G., Gastaldelli A., Del Ry S. Osteopontin in hepatocellular carcinoma: a possible biomarker for diagnosis and follow-up. Cytokine 2017; 99: 59-65, https:// doi.org/10.1016/j.cyto.2017.07.004.

122. Hao C., Cui Y., Owen S., Li W., Cheng S., Jiang W.G. Human osteopontin: potential clinical applications in cancer (review). Int J Mol Med 2017; 39(6): 1327-1337, https://doi. org/10.3892/ijmm.2017.2964.

123. Zhao H., Chen Q., Alam A., Cui J., Suen K.C., Soo A.P., Eguchi S., Gu J., Ma D. The role of osteopontin in the progression of solid organ tumour. Cell Death Dis 2018; 9(3): 356, https://doi.org/10.1038/s41419-018-0391-6.

124. Bruha R., Jachymova M., Petrtyl J., Dvorak K., Lenicek M., Urbanek P., Svestka T., Vitek L. Osteopontin: a non-invasive parameter of portal hypertension and prognostic marker of cirrhosis. World J Gastroenterol 2016; 22(12): 34413450, https://doi.org/10.3748/wjg.v22.i12.3441.

125. Fouad S.A., Mohamed N.A.G., Fawzy M.W., Moustafa D.A. Plasma osteopontin level in chronic liver disease and hepatocellular carcinoma. Hepat Mon 2015; 15(9): e30753, https://doi.org/10.5812/hepatmon.30753.

126. Yahya S.M.M., Fathy S.A., El-Khayat Z.A., El-Toukhy S.E., Hamed A.R., Hegazy M.G.A., Nabih H.K. Possible role of microRNA-122 in modulating multidrug resistance of hepatocellular carcinoma. Indian J Clin Biochem 2018; 33(1): 21-30, https://doi.org/10.1007/s12291-0170651-8.

127. Lokman N.A., Ween M.P., Oehler M.K., Ricciardelli C. The role of annexin $\mathrm{A} 2$ in tumorigenesis and cancer progression. Cancer Microenviron 2011; 4(2): 199-208, https:// doi.org/10.1007/s12307-011-0064-9.

128. Tressler R.J., Updyke T.V., Yeatman T., Nicolson G.L. Extracellular annexin II is associated with divalent cationdependent tumor cell-endothelial cell adhesion of metastatic RAW117 large-cell lymphoma cells. J Cell Biochem 1993; 53(3): 265-276, https://doi.org/10.1002/jcb.240530311.

129. Díaz V.M., Hurtado M., Thomson T.M., Reventós J., Paciucci R. Specific interaction of tissue-type plasminogen activator (t-PA) with annexin II on the membrane of pancreatic cancer cells activates plasminogen and promotes invasion in vitro. Gut 2004; 53(7): 993-1000, https://doi.org/10.1136/ gut.2003.026831.

130. Sharma M.R., Koltowski L., Ownbey R.T., Tuszynski G.P., Sharma M.C. Angiogenesis-associated protein annexin II in breast cancer: selective expression in invasive breast cancer and contribution to tumor invasion and progression. Exp Mol Pathol 2006; 81(2): 146-156, https://doi. org/10.1016/j.yexmp.2006.03.003.

131. Shiozawa Y., Havens A.M., Jung Y., Ziegler A.M., Pedersen E.A., Wang J., Wang J., Lu G., Roodman G.D., Loberg R.D., Pienta K.J., Taichman R.S. Annexin II/annexin II receptor axis regulates adhesion, migration, homing, and growth of prostate cancer. J Cell Biochem 2008; 105(2): 370380, https://doi.org/10.1002/jcb.21835.

132. Lozada M.E., Chaiteerakij R., Roberts L.R. Screening for hepatocellular carcinoma and cholangiocarcinoma: can biomarkers replace imaging? Curr Hepatol Rep 2015; 14(2): 128-138, https://doi.org/10.1007/s11901-015-0261-y.

133. Li J., Gong W., Li X., Wan R., Mo F., Zhang Z., Huang P., Hu Z., Lai Z., Lu X., Zhao Y. Recent progress of Wnt pathway inhibitor dickkopf-1 in liver cancer. J Nanosci Nanotechnol 2018; 18(8): 5192-5206, https://doi.org/10.1166/ jnn.2018.14636.

134. Zhou Y., Li W., Tseng Y., Zhang J., Liu J. Developing slow-off dickkopf-1 aptamers for early-diagnosis of 
hepatocellular carcinoma. Talanta 2019; 194: 422-429, https:// doi.org/10.1016/j.talanta.2018.10.014.

135. Pinato D.J., Mauri F.A., Lloyd T., Vaira V., Casadio C., Boldorini R.L., Sharma R. The expression of Axl receptor tyrosine kinase influences the tumour phenotype and clinical outcome of patients with malignant pleural mesothelioma. Br J Cancer 2013; 108(3): 621-628, https://doi.org/10.1038/bjc.2013.9.

136. Axelrod H., Pienta K.J. Axl as a mediator of cellular growth and survival. Oncotarget 2014; 5(19): 8818-8852, https://doi.org/10.18632/oncotarget.2422.

137. Byers L.A., Diao L., Wang J., Saintigny P., Girard L., Peyton M., Shen L., Fan Y., Giri U., Tumula P.K., Nilsson M.B., Gudikote J., Tran H., Cardnell R.J., Bearss D.J., Warner S.L., Foulks J.M., Kanner S.B., Gandhi V., Krett N., Rosen S.T., Kim E.S., Herbst R.S., Blumenschein G.R., Lee J.J., Lippman S.M., Ang K.K., Mills G.B., Hong W.K., Weinstein J.N., Wistuba I.I., Coombes K.R., Minna J.D., Heymach J.V. An epithelial-mesenchymal transition gene signature predicts resistance to EGFR and PI3K inhibitors and identifies $A x l$ as a therapeutic target for overcoming EGFR inhibitor resistance. Clin Cancer Res 2013; 19(1): 279-290, https://doi.org/10.1158/1078-0432.ccr-12-1558.

138. D'Alfonso T.M., Hannah J., Chen Z., Liu Y., Zhou P., Shin S.J. Axl receptor tyrosine kinase expression in breast cancer. J Clin Pathol 2014; 67(8): 690-696, https://doi. org/10.1136/jclinpath-2013-202161.

139. Dunne P.D., McArt D.G., Blayney J.K., Kalimutho M., Greer S., Wang T., Srivastava S., Ong C.W., Arthur K., Loughrey M., Redmond K., Longley D.B., Salto-Tellez M., Johnston P.G., Van Schaeybroeck S. AXL is a key regulator of inherent and chemotherapy-induced invasion and predicts a poor clinical outcome in early-stage colon cancer. Clin Cancer Res 2014; 20(1): 164-175, https://doi.org/10.1158/1078-0432. ccr-13-1354.

140. Paccez J.D., Vogelsang M., Parker M.I., Zerbini L.F. The receptor tyrosine kinase Axl in cancer: biological functions and therapeutic implications. Int J Cancer 2014; 134(5): 10241033, https://doi.org/10.1002/ijc.28246.

141. Hodeib H., ELshora O., Selim A., Sabry N.M., ElAshry H.M. Serum midkine and osteopontin levels as diagnostic biomarkers of hepatocellular carcinoma. Electron Physician 2017; 9(1): 3492-3498, https://doi.org/10.19082/3492.

142. Mashaly A.H., Anwar R., Ebrahim M.A., Eissa L.A., El Shishtawy M.M. Diagnostic and prognostic value of talin-1 and midkine as tumor markers in hepatocellular carcinoma in Egyptian patients. Asian Pac J Cancer Prev 2018; 19(6): 1503-1508.

143. Lindner K., Gregán J., Montgomery S., Kearsey S.E. Essential role of MCM proteins in premeiotic DNA replication. Mol Biol Cell 2002; 13(2): 435-444, https://doi.org/10.1091/ mbc. $01-11-0537$.

144. Liu M., Hu Q., Tu M., Wang X., Yang Z., Yang G., Luo R. MCM6 promotes metastasis of hepatocellular carcinoma via MEK/ERK pathway and serves as a novel serum biomarker for early recurrence. J Exp Clin Cancer Res 2018; 37(1): 10, https://doi.org/10.1186/s13046-017-0669-z.

145. Liu Z., Li J., Chen J., Shan Q., Dai H., Xie H., Zhou L., Xu X., Zheng S. MCM family in HCC: MCM6 indicates adverse tumor features and poor outcomes and promotes S/G2 cell cycle progression. BMC Cancer 2018; 18(1): 200, https://doi. org/10.1186/s12885-018-4056-8.

146. Laurent T.C., Moore E.C., Reichard P. Enzymatic synthesis of deoxyribonucleotides. IV. Isolation and characterization of thioredoxin, the hydrogen donor from Escherichia Coli B. J Biol Chem 1964; 239: 3436-3444.

147. Mollbrink A., Jawad R., Vlamis-Gardikas A., Edenvik P., Isaksson B., Danielsson O., Stål P., Fernandes A.P. Expression of thioredoxins and glutaredoxins in human hepatocellular carcinoma: correlation to cell proliferation, tumor size and metabolic syndrome. Int J Immunopathol Pharmacol 2014; 27(2): 169-183, https://doi.org/10.1177/0394632014027 00204.

148. Gunes A., Bagirsakci E., Iscan E., Cakan-Akdogan G., Aykutlu U., Senturk S., Ozhan G., Erdal E., Nart D., Barbet F.Y., Atabey N. Thioredoxin interacting protein promotes invasion in hepatocellular carcinoma. Oncotarget 2018; 9(96): 36849 36866, https://doi.org/10.18632/oncotarget.26402.

149. Cho S.Y., Kim S., Son M.J., Rou W.S., Kim S.H., Eun H.S., Lee B.S. Clinical significance of the thioredoxin system and thioredoxin-domain-containing protein family in hepatocellular carcinoma. Dig Dis Sci 2019; 64(1): 123-136, https://doi.org/10.1007/s10620-018-5307-x.

150. Fox R., Berhane S., Teng M., Cox T., Tada T., Toyoda H., Kumada T., Kagebayashi C., Satomura S., Johnson P.J. Biomarker-based prognosis in hepatocellular carcinoma: validation and extension of the BALAD model. $\mathrm{Br}$ J Cancer 2014; 110(8): 2090-2098, https://doi.org/10.1038/ bjc. 2014.130 .

151. Johnson P.J., Pirrie S.J., Cox T.F., Berhane S., Teng M., Palmer D., Morse J., Hull D., Patman G., Kagebayashi C., Hussain S., Graham J., Reeves H., Satomura S. The detection of hepatocellular carcinoma using a prospectively developed and validated model based on serological biomarkers. Cancer Epidemiol Biomarkers Prev 2014; 23(1): 144-153, https://doi. org/10.1158/1055-9965.epi-13-0870.

152. Berhane S., Toyoda H., Tada T., Kumada T., Kagebayashi C., Satomura S., Schweitzer N., Vogel A., Manns M.P., Benckert J., Berg T., Ebker M., Best J., Dechêne A., Gerken G., Schlaak J.F., Weinmann A., Wörns M.A., Galle P., Yeo W., Mo F., Chan S.L., Reeves H., Cox T., Johnson P. Role of the GALAD and BALAD-2 serologic models in diagnosis of hepatocellular carcinoma and prediction of survival in patients. Clin Gastroenterol Hepatol 2016; 14(6): 875-886, https://doi.org/10.1016/j.cgh.2015.12.042.

153. Kotha S., Neong S., Patel K. Serum biomarkers for diagnosis and monitoring viral hepatitis and hepatocellular carcinoma. Expert Rev Mol Diagn 2018; 18(8): 713-722, https://doi.org/10.1080/14737159.2018.1496020. 